\title{
Nitrogen Fixation by US and Middle Eastern Chickpeas with Commercial and Wild Middle Eastern Inocula
}

\author{
Rita Abi-Ghanem, ${ }^{1}$ Lynne Carpenter-Boggs, ${ }^{2}$ Jeffrey L. Smith, ${ }^{3}$ and George J. Vandemark ${ }^{4}$ \\ ${ }^{1}$ Department of Crop and Soil Sciences, Washington State University, Pullman, WA 99164-6420, USA \\ ${ }^{2}$ Center for Sustaining Agriculture and Natural Resources, Washington State University, Pullman, \\ WA 99164-6420, USA \\ ${ }^{3}$ Land Management and Water Conservation Research Unit, USDA-ARS, Pullman, \\ WA 99164-6421, USA \\ ${ }^{4}$ Grain Legume Genetics and Physiology Research Unit, USDA-ARS, Pullman, WA 99164-6434, USA
}

Correspondence should be addressed to Rita Abi-Ghanem, rita_ag@wsu.edu

Received 16 December 2011; Accepted 29 January 2012

Academic Editor: Y. Feng

Copyright ( $) 2012$ Rita Abi-Ghanem et al. This is an open access article distributed under the Creative Commons Attribution License, which permits unrestricted use, distribution, and reproduction in any medium, provided the original work is properly cited.

Chickpeas (Cicer arietinum L.) are native to the Middle East (ME) and must be inoculated with symbiotic bacteria (Mesorhizobium ciceri) to fix nitrogen $(\mathrm{N})$ in North American soils. Whether commercial M. ciceri strains are more or less effective than wild strains from ME soils when paired with various chickpea hosts must be elucidated. Wild N-fixing bacterial strains were isolated from ME soils, and their effectiveness was compared against commercial strains on US and ME chickpea varieties. Chickpeas were inoculated with individual strains and grown in chambers for 8 weeks. Plants received $2 \mathrm{mM}\left({ }^{15} \mathrm{NH}_{4}\right)_{2} \mathrm{SO}_{4}(5 \%$ atom excess) to measure $\mathrm{N}$ fixation by isotope dilution. Plant below- and above-ground biomass and proportion of $\mathrm{N}$ fixed (PNF) were determined. Commercial and wild ME strains were examined for genetic diversity by sequencing their 16S rDNA region. The PNF was significantly influenced by inoculant strains and chickpea varieties. Among varieties, Sierra, Troy, and Almaz had the highest PNF of $86.7 \%, 85.3 \%$, and $85.2 \%$, respectively. Among strains, Jord-M1 contributed to greater PNF (84.7\%) compared to Syr-M1 (81.4\%). Overall, chickpea varieties had greater effect on PNF than strain selection. These findings support efforts focusing on varietal breeding and strain selection to increase agricultural $\mathrm{N}$ fixation.

\section{Introduction}

Global demand for nitrogen fertilizer is predicted to increase $1.4 \%$ annually, which includes a 23.1 million tonnes increase by 2012 [1]. In the US, $\mathrm{N}$ fertilizer costs approximately tripled from 2002-2011 [2]. Although prices have decreased somewhat from the 2008 peak, the loss of billions of dollars in farm profit has drawn attention to the need for alternative sources of $\mathrm{N}$. The primary feedstock for synthetic nitrogen fertilizer is natural gas, both as a source of hydrogen and energy [3]. The US is estimated to have only $3.7 \%$ of the world natural gas reserves [4], which suggests that American agriculture would benefit from less expensive and more sustainable $\mathrm{N}$ sources.

Chickpea (Cicer arietinum L.), a drought-resistant legume from the Middle East (ME), has been cultivated for over
10,000 years [5]. Chickpeas belong to two major types, desi and kabuli. Desi varieties have a small dark seed with a rough coat while kabuli seeds are larger with lighter color and smoother coat [6]. In the US, 51,435 ha were planted with chickpeas in 2011 with a total production of 103,179 tonnes [7]. Chickpeas form root nodules that support biological $\mathrm{N}$ fixation (BNF) and host symbiotic $\mathrm{N}$-fixing bacteria. On average the estimated amounts of $\mathrm{N}$ fixed by chickpeas under regular precipitation and drought stress conditions are $60 \mathrm{~kg} / \mathrm{ha}$ [8] and 19-24 kg/ha [9], respectively.

There is increasing evidence that suggests that more $\mathrm{N}$ can be fixed by existing legume grain crops if they are inoculated more often or with more effective strains of rhizobia [10]. Significant increases in BNF can result from the use of different commercial or wild strains [11]. The efficiency of biological $\mathrm{N}$ fixation is also influenced by cultivars' selection; 
significant differences were observed among pea cultivars for the percentage of plant $\mathrm{N}$ supplied by bacterial $\mathrm{N}$ fixation and also for the number of root nodules formed per plant in a greenhouse experiment [12]. The known N-fixing symbiont of chickpea, M. ciceri, is not native to North American soils, and the number of commercial strains is limited. In addition, there has been little work to enhance the ability of chickpeas to support $\mathrm{N}$ fixation [13]. Plant breeders may be able to improve chickpea varieties through the use of breeding lines that are better $\mathrm{N}$-fixing symbiont hosts and could increase the BNF process.

The objectives of this study were to isolate and identify new N-fixing symbiont strains for chickpea from ME soil and to compare the BNF effectiveness of the new strains and current commercial strains when paired with US and ME varieties of chickpeas.

\section{Materials and Methods}

2.1. N Fixation Study. Soil was collected at $10-15 \mathrm{~cm}$ depth from non-inoculated chickpea fields in the following Middle Eastern cities with the help of the following collaborating entities: (1) Terbol, Lebanon (American University of Beirut (AUB)), (2) Tal Hadya, Syria (International Center for AgriculturaI Research in the Dry Areas (ICARDA)), (3) Erbid, Jordan (National Center for Agricultural Research and Technology Transfer of the Ministry of Agriculture (NCARTT)), and (4) Yozgat, Turkey (International Maize and Wheat Improvement Center (CYMMIT)). To isolate symbiotic BNF bacteria from these soils, chickpea seeds (Arman and Sierra) were sterilized with $0.5 \%$ sodium hypochlorite for three minutes and germinated for 5 days on sterile filter paper. Germinated seeds were planted in $164 \mathrm{~mL}$ seedling cones (SC10 container, Stuewe \& Sons, Inc.) filled with sterile sand and perlite (1:1 volume) and inoculated with $10 \mathrm{~mL}$ of $10^{-1}$ soil solution. The pots $(4 \mathrm{~cm} \times 20 \mathrm{~cm})$ were placed for 8 wks in growth chambers at $20^{\circ} \mathrm{C}$ and 16 hrs light. At harvest, large red nodules were selected, surface sterilized for $1 \mathrm{~min}$ with $0.5 \%$ sodium hypochlorite, and a loop of inoculum was streaked on Yeast Extract Mannitol Agar (YEMA). Two nodules were collected from two different plants per soil, to produce a total of eight wild strains isolated from single colonies (Leb-M1, Leb-M2, Syr-M1, Syr-M2, JordM1, Jord-M2, Turk-M1, Turk-M2). Commercial strains of mesorhizobia were also provided from Novozyme Biologicals (NB-M4, NB-M5, NB-M6, NB-M7, NB-M8), Becker Underwood (BU-M3), and EMD (EMD-M1). Three varieties of US chickpeas (Myles, Troy, and Sierra) were supplied by the USDA-ARS Grain Legume Genetics-Physiology Research Unit, Pullman, WA, and three ME varieties (Arman, Almaz, and Hashem) were supplied from the U.S. National Plant Germplasm System, Regional Plant Introduction Station in Pullman, WA. Five days before seed inoculation, strains were grown in $1 \mathrm{X}$ yeast extract broth at $22^{\circ} \mathrm{C}$ on an orbital shaker. Cells were collected by centrifugation at $4000 \mathrm{rpm}$ for $4 \mathrm{~min}$. An optical density $(\mathrm{A}=0.3)$ corresponding to a bacterial count of $10^{6}-10^{7}$ was determined using a spectrophotometer at $640 \mathrm{~nm}$ wavelength. Inocula were diluted to $10^{5}-10^{6}$ cfu per $\mathrm{mL}$. One $\mathrm{mL}$ of wild (Leb-M1, Syr-M1, Jord-M1, Turk-M1) or commercial diluted inocula (NB-M4, NB-M5, BU-M3, EMD-M1) was added to each cone, which contained one chickpea seed. Arman was also inoculated with an additional four wild (Leb-M2, Syr-M2, Jord-M2, Turk-M2) and four commercial strains (NB-M6, NB-M7, NB-M8, EMD-M6).

Treatments were a factorial design of two main factors, rhizobial strain and crop variety. Varieties by strain pairings were grown in $164 \mathrm{~mL}$ seedling cones filled with sandperlite mixture ( $1: 1$ volume) using five replicates. For precise measurement of biological $\mathrm{N}$ fixation, an isotopic $15-\mathrm{N}$ method was used. Two conditions must exist for the effective use of the isotope dilution method for determining BNF: (1) the addition of $\mathrm{N}$ should be low and (2) the $\mathrm{N}$ addition should be thoroughly mixed in the medium [14-16].

Plants were irrigated with $10 \mathrm{~mL} 2 \mathrm{mM}\left({ }^{15} \mathrm{NH}_{4}\right)_{2} \quad \mathrm{SO}_{4}$ (5\% atom excess) three times a week for the first two weeks, and with $\mathrm{H}_{2} \mathrm{O}$ thereafter [15]. Sterile $\mathrm{N}$-free Hoagland solution was added once a week to provide all necessary nutrients except $\mathrm{N}$. After 8 weeks, the whole plants were harvested and dried at $65^{\circ} \mathrm{C}$, after which above-ground biomass (AGB) and below-ground biomass (BGB) were separated at the root crown, and weighed. Atom percent ${ }^{15} \mathrm{~N} /{ }^{14} \mathrm{~N}(\mathrm{~A} \%)$ of combined AGB and BGB was measured by an isotope ratio mass spectrometer (Thermo-Finigan, Delta Plus Advantage). The atom \% excess (A\% - 0.366 A\%) was used to calculate the proportion of $\mathrm{N}$ fixed (PNF): $\mathrm{PNF}=$ $1-\left[\%\right.$ atom excess ${ }^{15} \mathrm{~N}$ in fixing crop/\% atom excess ${ }^{15} \mathrm{~N}$ in nonfixing crop] $\times 100$ [18]. Wheat was used as a control in the experiment as described by Knowles and Blackburn [19] and Smith et al. [20].

Five replicates were distributed in a randomized complete block design blocked by time. Analysis of variance (ANOVA) and correlations between various parameters were determined using SAS system for Windows version 9.1. Means were calculated with LSM in Proc Mixed. Data were considered significantly different at $P \leq 0.05$ according to Tukey's method in Proc Mixed.

2.2. PCR, Sequencing and Sequence Analysis. Genomic DNA was extracted with a Fast DNA SPIN KIT (MP Biomedicals Inc, OH) from seven commercial (EMD-M1, BU-M3, NBM4, NB-M5, NB-M6, NB-M7, and NB-M8) and four wild (Leb-M1, Turk-M2, Syr-M2, and Jord-M1) isolates. In addition, DNA was extracted from two commercial strains of Rhizobium leguminoserum bv. viciae (NB-R2, NB-R7). Using the primer pair fD1 (5'-AGAGTTTGATCCTGGCTCAG-3') and $\mathrm{rD1}$ (5'-AAGGAGGTGATCCAGCC-3'), an approximately $1340 \mathrm{bp}$ product specific to nearly full length of $16 \mathrm{~S}$ rRNA gene was amplified by PCR [21]. Cycling conditions were as follows: one cycle of $95^{\circ} \mathrm{C}$ for $2 \mathrm{~min}$ followed by 30 cycles of $94^{\circ} \mathrm{C}$ for $40 \mathrm{~s}, 52^{\circ} \mathrm{C}$ for $40 \mathrm{~s}$, and $72^{\circ} \mathrm{C}$ for $1 \mathrm{~min}$. This was followed by a final extension at $72^{\circ} \mathrm{C}$ for $7 \mathrm{~min}$. Amplicons were resolved on a $1.5 \%$ agarose $(1 \mathrm{X}$ TBE, $90 \mathrm{mM}$ Tris $\mathrm{pH}$ 8.0, $90 \mathrm{mM}$ boric acid, $2 \mathrm{mM}$ EDTA) gel, stained with ethidium bromide, and visualized with UV light. The amplicons were purified using a QIAquick PCR 
TABLE 1: Mean* \% N fixation, above-ground biomass (AGB), below-ground biomass (BGB), and seed weight in chickpeas ( $n=40$ except for seeds $n=20)$.

\begin{tabular}{|c|c|c|c|c|}
\hline Variety & $\mathrm{N}$ fixed $(\%)$ & AGB (dry mg plant ${ }^{-1}$ ) & BGB (dry mg plant ${ }^{-1}$ ) & Seed weight $(\mathrm{mg})$ \\
\hline Sierra $(K)^{\mathrm{a}}$ & $86.7^{\mathrm{a}}$ & $283^{a}$ & $319^{\mathrm{bc}}$ & 568 \\
\hline Troy (K) & $85.3^{\mathrm{ab}}$ & $264^{\mathrm{a}}$ & $374^{\mathrm{ab}}$ & 604 \\
\hline $\operatorname{Almaz}(\mathrm{K})$ & $85.2^{\mathrm{ab}}$ & $255^{\mathrm{ab}}$ & $386^{\mathrm{a}}$ & 496 \\
\hline $\operatorname{Arman}(\mathrm{K})$ & $83.2^{\mathrm{b}}$ & $228^{\mathrm{bc}}$ & $357^{\mathrm{ab}}$ & 396 \\
\hline Hashem (K) & $82.9^{\mathrm{b}}$ & $200^{c}$ & $296^{\mathrm{cd}}$ & 282 \\
\hline Myles (D) & $76.6^{c}$ & $154^{\mathrm{d}}$ & $271^{\mathrm{d}}$ & 164 \\
\hline$P$ values & $<0.0001$ & $<0.0001$ & $<0.0001$ & \\
\hline \multicolumn{5}{|l|}{ Contrast } \\
\hline US varieties & 82.9 & 234 & 321 & \\
\hline Middle Eastern & 83.8 & 228 & 346 & \\
\hline$P$ value & 0.128 & 0.412 & 0.007 & \\
\hline
\end{tabular}

${ }^{*}$ Letters that are the same within a column are not significantly different at $P \leq 0.05$.

${ }^{\mathrm{a}} \mathrm{K}$ : Kabuli type seed; D: Desi type seed.

TABLE 2: Strain effect on \% of plant $\mathrm{N}$ supplied by fixation in chickpeas $(n=30)$.

\begin{tabular}{lc}
\hline Strain & N fixed $(\%)^{*}$ \\
\hline Jord-M1 & $84.7^{\mathrm{a}}$ \\
BU-M3 & $84.3^{\mathrm{ab}}$ \\
NB-M4 & $84.3^{\mathrm{ab}}$ \\
NB-M7 & $83.3^{\mathrm{ab}}$ \\
EMD-M1 & $83.2^{\mathrm{ab}}$ \\
Turk-M1 & $82.9^{\mathrm{ab}}$ \\
Leb-M1 & $82.5^{\mathrm{ab}}$ \\
Syr-M1 & $81.4^{\mathrm{b}}$ \\
$P$ value & 0.045 \\
\hline Contrast & \\
$\quad$ Middle East strains & 82.9 \\
Commercial strains & 83.8 \\
$P$ value & 0.107 \\
\hline
\end{tabular}

${ }^{*}$ Letters that are the same within a column are not significantly different at $P \leq 0.05$.

Purification kit (QIAGEN Inc, CA) following manufacturer's instructions, and the purified DNA samples were sequenced in both orientations using the ABI PRISM 377 DNA Sequencer (Applied Biosystems Inc, CA). Sequences were edited, and a consensus sequence for each amplicon was derived using Vector NTI Advance 11 (Invitrogen Inc, CA). Consensus sequences were compared with GenBank accessions by a BLAST search [22]. Multiple sequence alignments were performed by ClustalW [23]. Phylogenetic analyses by the neighbor-joining method and a consensus tree were generated using Molecular Evolutionary Genetics Analysis (MEGA) software version 4.0 [24].

\section{Results}

3.1. Fixed $N$. Varieties and strains both had a major influence on the PNF. Averaged across all strains, Sierra had greater PNF than Arman, Hashem, and Myles (Table 1). Myles had a lower PNF than all other varieties. The selection of Sierra could increase PNF in the plant 13.2\% over Myles. Varieties from the US and ME were statistically similar in PNF.

Averaged across all varieties, strain Jord-M1 had greater PNF than Syr-M1 (Table 2), but the difference was small. The Jord-M1 strain provided an average $84.7 \%$ PNF compared to $81.4 \%$ using Syr-M1. Strains from the US and ME provided statistically similar levels of PNF.

3.2. Above- and Below-Ground Biomass. Varieties substantially influenced above and below-ground biomass $(P<$ 0.0001) (Table 1). Sierra and Troy had higher AGB than Arman, Hashem, and Myles. The AGB in Almaz was statistically similar to Sierra, Troy, and Arman and greater than Hashem and Myles (Table 1). This could be due to the larger seed size of these varieties. The average weight per seed in Sierra, Troy, and Almaz was, respectively $0.57 \mathrm{~g}, 0.60 \mathrm{~g}$, and $0.50 \mathrm{~g}$ while Myles weighed $0.16 \mathrm{~g}$ (Table 1). Almaz, Arman, and Troy had greater BGB than Myles, Hashem, and Sierra. The BGB in Troy was statistically similar to Sierra, Almaz, and Arman but greater than Hashem, and Myles (Table 1). The ME varieties had significantly greater BGB than the US varieties, which could be directly or indirectly related to the breeding traits selected in the US and ME. A greater BGB may provide the $\mathrm{ME}$ varieties a greater or wider tolerance to adverse environmental factors such as water stress. The PNF was highly correlated to AGB $(r=0.69 ; P<0.0001)$ and BGB $(r=0.32 ; P<0.0001)$, indicating that generally the larger plants had a lower proportion of plant $\mathrm{N}$ supplied by the fertilizer.

Arman tests with four additional ME and four additional commercial strains did not reveal a significant difference among these strains on the measured parameters (data not shown). All commercial and ME strains used in this trial were infective and effective on Arman.

3.3. Sequence Analysis. Wild ME nodulators and commercial inoculant strains separated into distinct phylogenetic clades, which were also distinct from the R. leguminoserum outgroup 


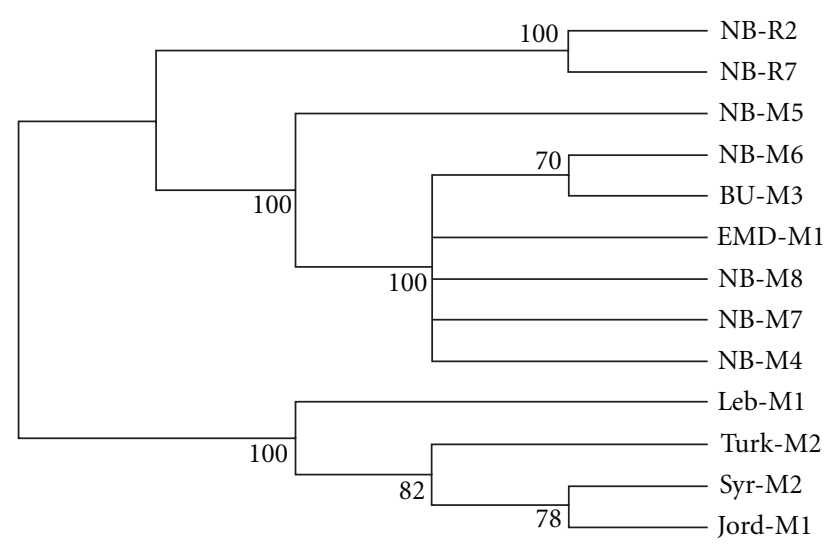

FIgURe 1: Phylogenetic analysis of $16 \mathrm{~S}$ ribosomal RNA sequences of commercial and wild chickpea symbionts. Tree constructed using Neighbor-Joining implemented in MEGA4 program [17]. Bootstraps values (1,000 replicates) are given at the branch nodes; branches reproduced in less than $70 \%$ of bootstrap replicates are collapsed. Isolates NB-R2 and NB-R7 are an outgroup of commercial strains of Rhizobium leguminosarum bv. viciae. Isolates EMD-M1, BU-M3, NB-M4, NB-M5, NB-M6, NB-M7, and NB-M8 are commercial chickpea inoculant strains of M. ciceri. Isolates LebM1, Turk-M2, Syr-M2, and Jord-M1 are wild chickpea nodulating isolates from Middle Eastern soils.

(Figure 1). One commercial strain, NB-M5, was also distinct from all other isolates. A BLAST search of $16 \mathrm{~S}$ rDNA sequences identified all commercial strains as $M$. ciceri and all wild ME symbionts as Burkholderia sp. Syr-M2 had 99\% sequence identity with Burkholderia fungorum, Jord-M1 had 99\% sequence identity with Burkholderia cepacia, and TurkM2 and Leb-M1 were identified only as Burkholderia sp. Wild ME symbiont sequences were 97-98\% similar among them, but only $79-80 \%$ similar to commercial strains of $M$. ciceri and $80-81 \%$ similar to $R$. leguminoserum (data not shown). This is the first report of Burkholderia that nodulates chickpea.

\section{Discussion}

In this study we used a nonlegume crop as a control and isotope dilution methods to track the proportion of $\mathrm{N}$ fixed [19] via Fried and Middleboe's equation [18]. The total $\mathrm{N}$ considered "fixed" in Fried and Middleboe's equation actually originates from all nonfertilizer sources. There was a positive correlation $(r=0.80)$ between the weight of the seeds and PNF in the harvested plant. An increase in the seed weight corresponded to an increase in PNF and suggests that ${ }^{14} \mathrm{~N}$ was supplied from the seeds. When seed $\mathrm{N}$ was subtracted from PNF as defined in Fried and Middleboe equation, only two varieties demonstrated true $\mathrm{N}$ fixation. Myles had $8.8 \%$ true PNF and Hashem had 14.5\% true PNF. In this case, Fried and Middleboe's equation for the determination of PNF that the plants derived from the atmosphere needs to be adjusted by subtracting the amount of $\mathrm{N}$ in the plant derived from the seeds.

The ability of Burkholderia sp. to symbiotically fix $\mathrm{N}$ on other legumes has been recognized recently. Bontemps et al.
[25] tested 143 symbionts from 47 Brazilian wild species of Mimosa and found that $98 \%$ were Burkholderia sp. Two strains of Burkholderia caribensis had been isolated previously from Mimosa nodules [26]. Burkholderia tuberum isolated from a South African legume has been proved to contain nod and nif genes similar to Rhizobiaceae and showed a genetic response with bean and cowpea [27]. Burkholderia cepacia, which was isolated from Acacia decurrens and Ormosia nitida in Brazil, contained nod $\mathrm{C}$ and nif $\mathrm{H}$ genes [28]. Several studies have demonstrated Burkholderia sp. isolated from nodules of papilionoid and other mimosoid legumes are able to form nodules on selective variety of legumes $[29,30]$. Burkholderia belongs to the betaproteobacteria class and carries similar nod genes to rhizobia, which are alphaproteobacteria. The transfer of nod genes to the new $\mathrm{N}$-fixing bacteria may have occurred via lateral gene transfer $[29,31]$.

Other research has demonstrated a strong influence of plant variety on $\mathrm{N}$ fixation. Bello et al. [32] found 70\% and $25 \%$ variability in $\mathrm{kg} \mathrm{N}$ fixed $\mathrm{ha}^{-1}$ among three soybean varieties at two sites. The survival and number of inocululated rhizobia are very critical for successful nodulation and yet limited efforts have been made to improve rhizobial inoculants [11]. Inoculated rhizobia strains may not compete well against resident rhizobia. Inoculation by commercial strains filled 5-20\% of nodules on soybeans in studies by Caldwell and Vest [33] and Kuykendall and Weber [34]. In these trials, variety had a stronger influence on PNF than did strain, and all strains tested were effective on all varieties. Consequently, the more efficient strategy for BNF improvement may be in breeding crops that support greater $\mathrm{N}$ fixation rather than rhizobia strain selection.

\section{Conclusion}

Increased BNF by legume-bacterial associations can be used to further improve global crop production or reduce the need for synthetic $\mathrm{N}$ fertilizers. As the cost of fertilizers increases, the value of improving BNF also increases. Variety of chickpeas had a greater effect on variation in PNF than did the symbionts strain. This study indicates the possibility to improve the efficiency of $\mathrm{N}$ fixation through selection of chickpea varieties that host effective symbionts and have a high demand for N. Four newly isolated N-fixing chickpea symbionts from Middle Eastern soils were identified as Burkholderia sp. Studies are needed to investigate additional $\mathrm{N}$-fixing bacteria beyond those found within the Rhizobiaceae. A new strain from Jordan, Jord-M1 contributed to the highest PNF. These findings suggest that variety selection may potentially improve PNF with a wide variety of symbionts, leading to higher yield, higher protein content, and/ or more residual $\mathrm{N}$ for following crops.

\section{Abbreviations}

PNF: Proportion of plant nitrogen provided by fixation

BNF: Biological nitrogen fixation

$\mathrm{N}$ : Nitrogen

ME: Middle East 
US: United States

AGB: Above-ground biomass

BGB: Below-ground biomass.

\section{References}

[1] FAO, Current World Fertilizer and Trends and Outlook to 20112012, FAO, Rome, Italy, 2008.

[2] USDA-ERS, Average U.S. Farm Prices of Selected Fertilizers, 1960-2011, 2011.

[3] IFA (International Fertilizer Industry Association), Greenhouse Gas Emissions and Fertilizer Production, 2009.

[4] EIA (U.S. Energy Information Administration), World Proved Reserves of Oil and Natural Gas, Most Recent Estimates, 2009.

[5] K. Albala, Beans: A History, Berg Publishers, New York, NY, USA, 2007.

[6] M. R. Naghavi and M. R. Jahansouz, "Variation in the agronomic and morphological traits of Iranian chickpea accessions," Journal of Integrative Plant Biology, vol. 47, no. 3, pp. 375-379, 2005.

[7] NASS National Agriculture Statistics Service, Quick Stats for Chickpeas (Garbanzo), 2011.

[8] M. J. Unkovich and J. S. Pate, "An appraisal of recent field measurements of symbiotic $\mathrm{N}_{2}$ fixation by annual legumes," Field Crops Research, vol. 65, no. 2-3, pp. 211-228, 2000.

[9] C. Carranca, A. De Varennes, and D. Rolston, "Biological nitrogen fixation by fababean, pea and chickpea, under field conditions, estimated by the ${ }^{15} \mathrm{~N}$ isotope dilution technique," European Journal of Agronomy, vol. 10, no. 1, pp. 49-56, 1999.

[10] J. Brockwell, R. R. Gault, D. F. Herridge, L. J. Morthorpe, and R. J. Roughly, "Studies on alternativemeans of legume inoculation: microbiological and agronomic appraisals of commercial procedures for inoculating soybeans with Bradyrhizobium japonicum," Australian Journal of Agricultural Research, vol. 40, pp. 753-762, 1989.

[11] J. Brockwell and P. J. Bottomley, "Recent advances in inoculant technology and prospects for the future," Soil Biology and Biochemistry, vol. 27, no. 4-5, pp. 683-697, 1995.

[12] R. Abi-Ghanem, L. Carpenter-Boggs, and J. L. Smith, "Cultivar effects on nitrogen fixation in peas and lentils," Biology and Fertility of Soils, vol. 47, pp. 115-120, 2011.

[13] C. P. Horn, R. C. Dalal, C. J. Birch, and J. A. Doughton, "Nitrogen fixation in chickpeas as affected by planting time and tillage practice," in Proceedings of the 8th Australian Agronomy Conference, D. L. Michalk and J. E. Pratley, Eds., pp. 1-5, Queensland, Australia, February 1996.

[14] P. M. Chalk, "Estimation of $\mathrm{N}_{2}$ fixation by isotope dilution: an appraisal of techniques involving ${ }^{15} \mathrm{~N}$ enrichment and their application," Soil Biology and Biochemistry, vol. 17, no. 4, pp. 389-410, 1985.

[15] S. K. A. Danso, G. Hardarson, and F. Zapata, "Misconceptions and practical problems in the use of ${ }^{15} \mathrm{~N}$ soil enrichment techniques for estimating $\mathrm{N}_{2}$ fixation," Plant and Soil, vol. 152, no. 1, pp. 25-52, 1993.

[16] F. R. Warembourg, "Nitrogen fixation in soil and plant systems," in Nitrogen Isotope Techniques, R. Knowles and T. H. Blackburn, Eds., pp. 127-155, Academic Press, New York, NY, USA, 1993.

[17] K. Tamura, M. Nei, and S. Kumar, "Prospects for inferring very large phylogenies by using the neighbor-joining method," Proceedings of the National Academy of Sciences of the United States of America, vol. 101, no. 30, pp. 11030-11035, 2004.
[18] M. Fried and V. Middelboe, "Measurement of amount of nitrogen fixed by a legume crop," Plant and Soil, vol. 47, no. 3, pp. 713-715, 1977.

[19] R. Knowles and H. T. Blackburn, Nitrogen Isotope Techniques, Academic Press, San Diego, Calif, USA, 1993.

[20] S. C. Smith, D. F. Bezdicek, R. F. Turco, and H. H. Cheng, "Seasonal $\mathrm{N}_{2}$ fixation by cool-season pulses based on several ${ }^{15} \mathrm{~N}$ methods," Plant and Soil, vol. 97, no. 1, pp. 3-13, 1987.

[21] W. G. Weisburgh, S. M. Barns, D. A. Pelletier, and D. J. Lane, "16S ribosomal DNA amplification for phylogenic study," Journal of Bacteriology, vol. 173, pp. 697-703, 1991.

[22] S. F. Altschul, W. Gish, W. Miller, E. W. Myers, and D. J. Lipman, "Basic local alignment search tool," Journal of Molecular Biology, vol. 215, no. 3, pp. 403-410, 1990.

[23] J. D. Thompson, D. G. Higgins, and T. J. Gibson, "CLUSTAL $\mathrm{W}$ : improving the sensitivity of progressive multiple sequence alignment through sequence weighting, position-specific gap penalties and weight matrix choice," Nucleic Acids Research, vol. 22, no. 22, pp. 4673-4680, 1994.

[24] K. Tamura, J. Dudley, M. Nei, and S. Kumar, "MEGA4: molecular evolutionary genetics analysis (MEGA) software version 4.0," Molecular Biology and Evolution, vol. 24, no. 8, pp. 15961599, 2007.

[25] C. Bontemps, G. N. Elliott, M. F. Simon et al., "Burkholderia species are ancient symbionts of legumes," Molecular Ecology, vol. 19, pp. 44-52, 2010.

[26] K. Vermis, T. Coenye, J. J. Lipuma, E. Mahenthiralingam, H. J. Nelis, and P. Vandamme, "Proposal to accommodate Burkholderia cepacia genemovar VI as Burkholderia dolosa sp. nov," International Journal of Systematic and Evolutionary Microbiology, vol. 54, pp. 689-691, 2004.

[27] G. N. Elliott, W. M. Chen, C. Bontemps et al., "Nodulation of Cyclopia spp. (Leguminosae, Papilionoideae) by Burkholderia tuberum," Annals of Botany, vol. 100, no. 7, pp. 1403-1411, 2007.

[28] P. Menna, M. Hungria, F. G. Barcellos, E. V. Bangel, P. N. Hess, and E. Martínez-Romero, "Molecular phylogeny based on the $16 \mathrm{~S}$ rRNA gene of elite rhizobial strains used in Brazilian commercial inoculants," Systematic and Applied Microbiology, vol. 29, no. 4, pp. 315-332, 2006.

[29] L. Moulin, A. Munive, B. Dreyfus, and C. Boivin-Masson, "Nodulation of legumes by members of the $\beta$-subclass of Proteobacteria," Nature, vol. 411, no. 6840, pp. 948-950, 2001.

[30] C. F. Barrett and M. A. Parker, "Prevalence of Burkholderia sp. nodule symbionts on four mimosoid legumes from Barro Colorado Island, Panama," Systematic and Applied Microbiology, vol. 28, no. 1, pp. 57-65, 2005.

[31] A. Sy, E. Giraud, P. Jourand et al., "Methylotrophic Methylobacterium bacteria nodulate and fix nitrogen in symbiosis with legumes," Journal of Bacteriology, vol. 183, no. 1, pp. 214-220, 2001.

[32] A. B. Bello, W. A. Ceron-Dias, C. D. Nickell, E. O. Elsheriff, and L. C. Davis, "Influence of cultivar, between-row spacing and plant population of fixation of soybeans," Crop Science, vol. 20, pp. 751-775, 1980.

[33] B. E. Caldwell and G. Vest, "Effects of Rhizobium japonicum strains on soybean yields," Crop Science, vol. 10, pp. 19-21, 1970.

[34] L. D. Kuykendall and D. F. Weber, "Genetically marked Rhizobium identifiable as inoculum strain in nodules of soybean plants grown in fields populated with Rhizobium japonicum," Applied and Environmental Microbiology, vol. 36, pp. 15-919, 1978. 

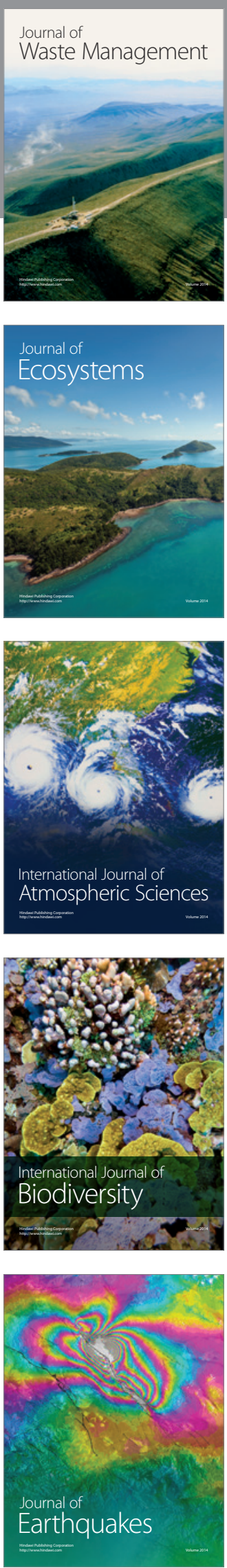
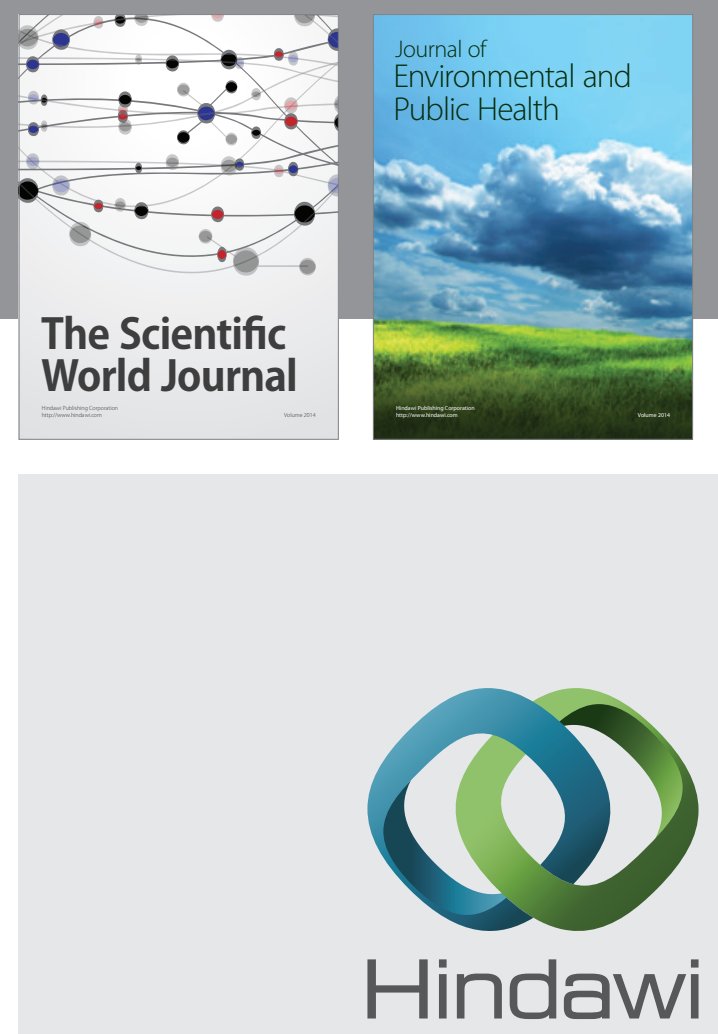

Submit your manuscripts at

http://www.hindawi.com
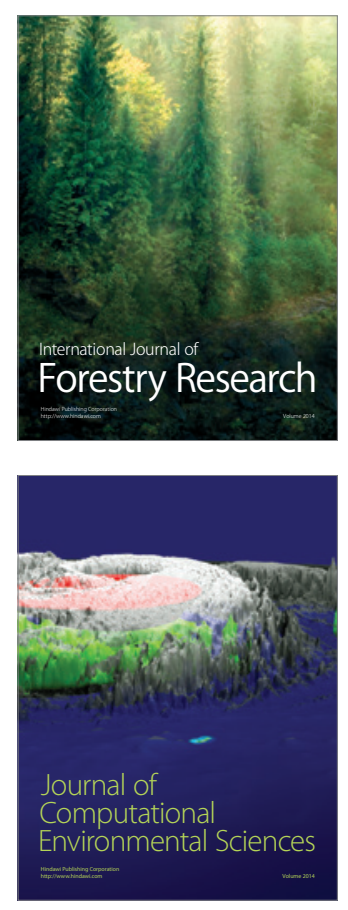
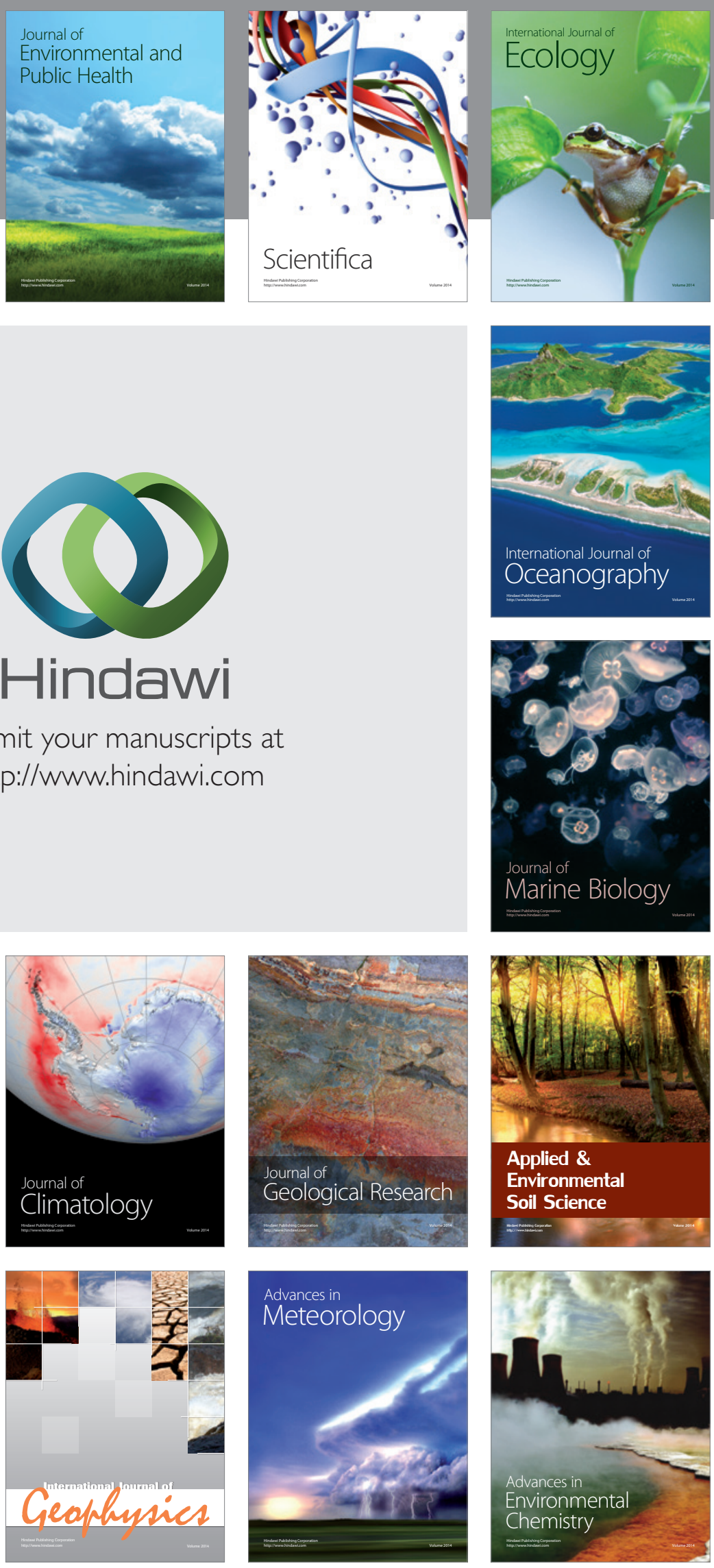